\title{
Peertechz
}

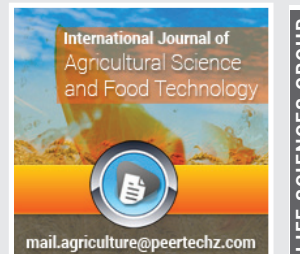

\section{Role and economic importance of crop genetic diversity in food security}

Received: 05 April, 2021

Accepted: 16 April, 2021

Published: 17 April, 2021

*Corresponding author: Temesgen Begna, Ethiopian Institute of Agricultural Research, Chiro National Sorghum Research and Training Center P. O. Box 190, Chiro, Ethiopia, E-Mail: tembegna@gmail.com

Keywords: Genetic diversity; Food security; Genetic base; Genetic erosion; Variability

https://www.peertechzpublications.com

\section{Temesgen Begna*}

Ethiopian Institute of Agricultural Research, Chiro National Sorghum Research and

Training Center P. O. Box 190, Chiro, Ethiopia

\section{Abstract}

Determination of genetic diversity and their relationships among breeding materials is very crucial in crop improvement strategies. Characterization and evaluation of germplasm is pre-requisite to screen out the desired genetic materials for the genetic improvement programs. The collection of germplasm relies on the several number of accessions it possesses and the genetic materials available in those accessions for yield and yield components. Climate change and geographical isolation are identified as two majors in the formation of new species. The other sources of germplasm diversification and evolution are biotic factors like competition and predation among themselves. Phenotypic characters are the most important conventional tools to analyse variation among the genetic materials and the visible morphological traits are very crucial tools in genetic diversity investigation. Plant breeding is primarily relied on the variation exist in the genetic diversity of cultivated and their wild relatives together for further improvements. Plant phenotyping is defined as the investigation of plant characters by researchers for yield, quality and resistance to biotic and abiotic stresses. Genetic variation and selection are the two basic principles of plant breeding. Additive (heritable) and non-additive variance (dominance and epitasis) are the important components of genetic variance of any quantitative traits. Hence, it is important to decompose the visible phenotypic variation into heritable and non-heritable components with suitable genetic components like genotypic coefficient of variation, heritability and genetic advance. Genetic diversity is the totality of genetic difference of genetic variation in the genetic make-up of a species. Genetic diversity ha paramount role in the perpetuation of a species through offering adaptation mechanisms to biotic and abiotic environmental stresses and enables change in the genetic composition to cope with changes in the environment. Eventually, plant genetic diversity is playing a key role in the continuation of agricultural development with significant improvement in different morphological and agronomical characteristics. Selection for improvement highly depends on inherent levels of genetic diversity present at the time in the species, rate of evolutionary response and adaptation to the environmental conditions. As the genetic diversity increases the ability to adapt to changing environments also increases within a given species. Especially, when the climate fluctuation, new pests and diseases are occurred, the species which have huge genetic diversity capable of overcome the challenges. Since crop plant improvement program is integrated with different research disciplines, the availability and accessibility of diverse genetic materials ensure the sustainability of global food production network.

\section{Introduction}

Biological diversity is the existence of variation among and within the living world for the betterment of improvement especially in crop plants [1]. Biological diversity is necessarily decomposed into three different major components such as genetic diversity, species diversity and ecosystem diversity [2]. Genetic diversity is the availability of variability of heritable traits in a population of the given species [3]. Genetic variation is defined as the differences in DNA sequence, biochemical characteristics, physiological and morphological characters such as plant height, flower position, flower color and other different function. Ramanatha \& Hodgkin, [2] described genetic diversity as the presence of difference in alleles, genotypes, the result of their performance (phenotypes) and the overall sum of genome. The utilization of genetic diversity is relevant for making advanced improvement for crop plants [4]. In the presence of narrow genetic diversity within crop species are susceptible to emerging pathogens and other several constraints leading to loss of productivity and this problem leads to serious decline in the areas of adaptation [5]. Genetic variation is a major driver of evolutionary diversification and source of phenotypic variation.

The achievement in the crop improvement primarily relies on the broad base of degree genetic divergence [6]. Genetic diversity has tremendous significance for the development of superior cultivars in crop improvement. In the crossing of different genetic materials, the superior performance and desirable hybrids are expected as compare to the crossing of similar genetic materials. Mahalanobis $\mathrm{D}^{2}$ statistics manifests very successful method that is relied on the genetic variability 
analysis which is a good indicator of genetic diversity. This system is required to be tested on wide ranges of crops to be verified [7]. The potential improvement of crop plants determined by the magnitude of genetic diversity available in provided crop species. Characterization followed by cataloguing of genetic materials are an essential prerequisite for a successful improvement program. Genetic diversity analysis tools are used to measure the degree of genetic divergence amongst different populations [8]. The presence of genetic variation in plant populations is useful for conservation and breeding programs.

Plant genetic diversity offers opportunity for researchers to develop new improved varieties with desirable traits, which accommodates both farmers and breeders preferred traits. Multitude techniques are continuously used to assess the genetic variability between and within crop plants population. This techniques are; (i) morphological, (ii) biochemical characterization or evaluation (allozyme), in the pregenomic era, and (iii) DNA (molecular) marker analysis especially single nucleotide polymorphism (SNPs) in postgenomic era. Crop genetic variation can be decomposed into between and within a crop cultivars. The extent of genetic variation between cultivars is a function of the genetic differences between the cultivars. Either natural or human driven, evolution is primarily relied on available genetic diversity in a population. As we know, systematic plant breeding starting with the utilization of natural variation available between crops. But over the progress of time, genetic variation reduced due to (i) lopsided breeding procedures focusing on improvement of few characters (yield and its component characters), (ii) frequent utilization of few selected parents in varietal development program and (iii) introduction of few varieties which leads to increased genetic similarity between modern crop cultivars. Increasing, crop genetic diversity is playing very critical role in the world food supply to feed the alarmingly increasing population [9]. This day the crop genetic diversity is decreased due to several reasons as compared to the previous one.

It is crucial to enhance the crop productivity through the providing the appropriate protection and conservation to genetic diversity of crops and the management practices of growing environments should be modified. Eventually, human population is increasing alarming and becoming beyond the expectation of life standard which caused the scarcity of natural resources [10]. Therefore, knowledge of genetic variability is the key component in selecting genotype that withstand to changing environments, including new pests, diseases and new climatic conditions for the future breeding program. The objective of the paper was to understand the role and economic importance of crop genetic diversity in food security.

\section{Concept of diversity and its impact in crop improvement}

Genetic diversity is defined as the availability of genetic variation which is heritable traits in a population of given species [3]. For the development of climate resilient cultivars, the existence of genetic diversity in the form of wild species, related species, breeding stocks and mutant lines are the source of desirable alleles which assist plant breeders [10].
Genetic diversity is the natural gift that arised due to mutation, gene flow hybridization and polyploidy of genetic materials. Genetic variation is the allelic differences of genes in DNA or RNA arrangements in the genetic pool of a population. Genetic diversity is the broadest term consisting all the variation existing between the different genetic materials in relation to genetic make-up of crop species. There is three level of categories of biological diversity. These are: ecosystem diversity which is the representation of variability between distinguished communities of species at the highest hierarchy. The second level of biological diversity is diversity in species which is indicating the different species within a community and the third biological diversity is genetic diversity which is the diversity present within distinguished cultivars of species.

Genetic diversity has significant role in ensuring food security through increasing farmer's income and plays in current and future food production [11]. The importance of plant genetic diversity is very large especially from the very beginning of agriculture, natural genetic variability has been exploited within crop species to meet subsistence food requirement, and now it is being focused to surplus food for growing populations. Today's crop gene banks have emerged in response to two different intended purposes: first, the mobilization, management, and long-term storage of materials that can be readily used in crop variety improvement programs and second, the long-term conservation of crop genetic diversity, for the potential future use of humanity. Crop genetic resources are the basis of agricultural production and significant economic benefits have resulted from their conservation and use. Genetic resources provide the fundamental mechanics that enable plants to convert soil, water and sunlight into something of critical value to humans-food. Diverse genetic resources allow humans to select and breed plants with desired characteristics, thus increasing agricultural productivity. Genetic diversity is the backbone of a nation's food security and the basis of economic development as a whole.

\section{Advantages of genetic diversity}

Genetic diversity is the base for crop improvement and existence of crop pant in nature. It clear that the genetic diversity offers opportunity for improvement of cultivars with desired traits which consist both farmer-preferred traits and breeder-preferred traits. To meet subsistence food requirement, genetic variability has been used in beginning of agriculture. Nowadays, climate adapted cultivar development is the issues of plant breeder since the climate components are fluctuated and causing adverse problems on the normal growth and development of crop plants. The availability of genetic diversity directly related with presence of desired alleles and help to develop in breeding climate resilient varieties. Sustainability of crop production and food security is being threatened by the increasing unpredictability and severity of drought stress due to global climate changes. The incorporation of the adapted natural genetic variations into breeding programs can enrich the current genetic diversity of stress tolerance and improve yield under stress. Genetic diversity enable for the development of high yields of farmers and breeders preferred improved quality cultivars. Genetic 
diversity also playing paramount role towards the development of potential varieties against new diseases, insect pests, extreme heat and extreme cold. Genetic diversity facilitates the development of varieties for specific traits like abiotic and biotic stresses tolerance and quality improvement. Food and Agriculture Organization reported the depletion of genetic diversity as the most serious environmental concerns [12]. In general, genetic diversity strictly the amount genetic variation available between crop species [13].

\section{Variability and adaptability}

The largest genetic variation of crop species offers the greater opportunities for improvement to adapt to environmental conditions. Adaptability is the better survival of a genotype over any specific environment. Adaptation to climate fluctuation is very critical issues in the food security discourse. There are a lot of factors involved in the adaptation of crop plants and the set of condition includes edaphic factors, environmental and biotic factors. The phenotype is the result of genotypes, environment and interaction of genotypes and environment [14]. Genotype $x$ environmental interaction is a prerequisite for crop plant improvement and evaluates the improved genotypes across multiple environments. The genotype by environment interaction results in non-stable performances between the genotypes across environments. The growth and development of crop plants are affected by complex interplay with the interaction of Environmental (E) and Management factors (M) [15]. Breeding program should strictly manages selection intensity during improvement since genetic diversity offers the essential basis for long term genetic gain. Adaptability is essentially relying on the availability of genetic variability within and between crop species.

\section{Factors affecting genetic diversity}

Genetic diversity is affected by several different factors. There is evolutionary forces continuously changing genetic frequencies of crop species which affects the genetic diversity of a population. Selection, mutation, gene flow and genetic drift are the evolutionary forces which affects gene pool of a given population. Genetic diversity is caused by multitude factors. Some of them are mentioned here under:

Evolution: The term agricultural evolution is summarized as changes crop plants over time due to natural and artificial selection, and modern breeding procedures [16]. Evolution started from wild form through passing different processes to generate the desired domesticates. Evolution is a gradual change by which the present diversity of plants arose from the earliest and primitive organisms [17]. Evolution is leading to transformation genetic diversity through gradual processes which finally resulted the new crop species. The theory of evolution developed by Charles Darwin dictated since 1859, which stated variation exists in initial population of plants and the best adapted individuals survive and reproduce in greater numbers over time [18]. Indeed, domesticated plants provide alternative materials for evolutionary genetics in the development of genomes architecture [19].
Domestication: Domestication is the choosing of desirable traits by neglecting other undesired traits which resulted in reducing the frequency of ignored alleles. Domestication is the transformation of wild progenitors to the cultivated species through continues selection for desirable traits of crop plants in order to satisfy the human demand [16]. Plants domesticated in different agro-ecological environments of the world for the different desirable traits that demanded by the cultivators. Domestication is about artificial selection of crop plants with the desired traits in order to ensure food and nutritional security [20]. There is genetic alteration of morphological and agronomical characters in domestication processes for adaptation of crop plants [21]. McCouch [22] indicated domestication is about adapting the high yielding varieties with resistance to biotic and abiotic stresses, improved nutritional quality, big seed and fruit size, non-shattering, reduction of seed dispersal mechanisms, a more compact growth habit, early matured crop plants. In the domestication process wild plants have been evolved into crop pants through artificial selection in order to satisfy the specific human demand. Artificial selection of crop plants causes alteration for the transformation of wild species to domesticate [23].

Plant Breeding: Plant breeding has profound impact on food production and will continue to play a vital role in world food security. Genetic diversity plays critical role in crop improvement because crossing between genetic materials of diverse origin which shows superiority over the closely related species. Plant breeding is primarily depends on presence of substantial genetic variation to address the maximum genetic yield potential of the crops and exploitation of this variation through effective selection for improvement [24]. Hence, plant breeding was launched earlier with plant domestication to develop the superior genotypes in terms of yield, resistance to diseases and insets and other many different traits [25]. Plant breeding has decreased the variation of genetic materials due to the limited preferences of crop plants for further improvements for different desirable traits.

Mutation: Mutations are the original source of genetic variation and primarily creates genetic diversity mutation can have positive, neutral and negative impacts in genetic alteration of crop species. Mutation is the sudden heritable changes of genetic diversity occurred occasionally through aberration of genetic materials like DNA, RNA and protein within the cells. Mutation has a great role in increasing genetic diversity in order to feed the increasing human population [26]. Mutation is primarily causes the alteration of genetic diversity. Genetic diversity is the variation occurred in genetic information, which depends on frequency and diversity of alleles among individuals within a population or a species. Mutation is the driving force for sustainable genetic diversity creation which uses in further improvement. Induced mutagenesis are broadening the genetic variation whereas conventional breeding approaches is narrowing genetic variability for improvement for long period of time. The utilization of mutation breeding are significantly generating crop genetic diversities through improvement of crops to improve the livelihood of the communities [27]. 
Migration: migration is the movement of crop plants between and within a species. It directly occurs through seed and pollen dispersal, vegetative propagules like suckers, rhizomes, in species that can reproduce vegetative. On the other hand migration is about gene flow occurs through moving from one to another areas and is resulted mixing of two or more genes of population through pollen and seed dispersal.

Selection: The selection of plants from a population is almost always based on their phenotype and the phenotype has both heritable and non-heritable components. Genetic improvement in crops depends on quality and magnitude of genetic variability available in the population as well as the nature of association between yield and its components. This enables simultaneous selection for many traits associated with yield [28]. Adequate variability provides options from which selections are made for improvement and possible hybridization.

\section{Effects of genetic erosion}

Genetic erosion is the depletion of genetic variability due to several factors over a particular period of time in a particular location. The loss can include individual genes or combination of genes. Genetic loss is the reduction of genetic diversity over time [29]. Genetic loss primarily caused due to the modernization of agriculture which embraces the replacement of landraces with the new improved varieties. The loss of genetic variation is becoming a bottleneck in plant breeding activities. Genetic loss can be occurred at three different levels: crop, variety and allele. Climate changes, deforestation, environmental degradation, urbanization, replacement of local land races are major cause of genetic loss. There are three different methods to quantify genetic loss: (1) Genetic erosion as a complete loss of a crop, variety or allele [30]. (2) Genetic erosion as an alleviation in richness [31]. (3) Genetic erosion as an alleviation in evenness [32]. Genetic loss as depletion in evenness originates from the variability indicators used in population genetics, such as Shannon's index [33] and Nei's gene diversity index [34]. Genetic diversity is measured using frequencies of genes within a group of genotypes in a specified region. Diversity level is reduced because of dominant single genotypes or alleles. Genetic loss at ex situ conservation can be occurred because of depletion of genes as a result of regeneration and storage practices [35].

\section{Narrowing genetic bases of crops}

Narrowing the genetic bases of crop plats are becoming a serious problems in the development new and superior varieties with useful characteristics. Depletion of genetic variation is not only about the replacement of a diversity of land races with one or a few modern varieties, but involves the loss of farmers' indigenous knowledge and ability to manage their own plant genetic resources. Narrow genetic base is very problematic in the modern agriculture that caused due to selection of best performed cultivars with the preferred traits. The main cause of narrow genetic base is the replacement of diversity of land races with few modern varieties. Genetic erosion has negative developmental effect when loss of genetic diversity has profoundly narrowed the genetic base of modern crop varieties [36]. Narrow genetic base is defined as the loss of genetic diversity and commonly refers to the reduction in the quantities of specimens of a species $[37,38]$. Green revolution was the transition of cultivation of landraces to modern varieties to increase the agricultural productivity using improved varieties, excessive agricultural inputs and mechanized agriculture. Replacement of landraces that evolved with and has been genetically improved by traditional agriculturists, but has not been influenced by modern breeding practices or traditional varieties by modern varieties or high yielding varieties is one of the most important reasons. The landraces of a primary centre of origin are assumed to contain many valuable genes particularly for resistance or tolerance to various biotic and abiotic stresses and hence hold promise for their utilization in future plant-breeding programs. The term genetic erosion is sometimes used in a narrow sense, i.e. the loss of genes or alleles, as well as more broadly, referring to the loss of varieties. There are a number of different ways to represent the problems of genetic erosion. One of the most useful indicators is the narrowness of the food base. Narrow genetic base is the depletion in population variation because of inbreeding and genetic drift which is largely causes the endangerment of small isolated populations. Narrowing of genetic diversity might result the complete loss of crop plants.

\section{Conclusion}

Genetic diversity is the extent of genetic variation available among crop species to use in improvement program. The presence of sufficient genetic variation is a key for the success of breeding program. Genetic diversity has paramount importance for the development of superior varieties in terms of yield and other desirable traits. It is also very crucial in the production of superior hybrids and desirable recombinants. Genetic diversity determines the efficiency and effectiveness of improvement which may result in enhanced food production. From plant breeding aspects, classification of genetic variability to respective heterotic group is critical for the development of vigorous and outstanding hybrids in terms of economically important traits. Genetic diversity is providing vital protection to other nature against climate change, pests and diseases stresses.

Creating sufficient genetic variation for golden crop improvement is becoming challenges to keep improving genetic yield potential. Nowadays, plant breeders are utilizing genetic materials without knowing its genetic background such as exotic non-adapted, exotic adapted and existing genetic material as a source of new alleles that protect and improve genetic gain through selection. In ensuring food and nutritional security, genetic diversity is contributing very amble quantity. Knowledge of genetic diversity of the genetic material is very critical in crop improvement. Effective selection is highly important in any crop improvement where the sufficient genetic variation is available for different characters. The genetic variability analysis of crop cultivars for different agronomical and morphological characters are very critical in providing opportunity to select a number of promising cultivars. Genetic variation is the basic foundation 
for the continuous development of new superior varieties. Hence characterization of genetic materials using different statistical tools is critical in the crop improvement program. Improvement for both qualitative and quantitative traits are primarily relying on the genetic diversity.

Generally, plant breeding primarily depends on presence of substantial genetic variation to address the maximum genetic yield potential of the crops and exploitation of this variation through effective selection for improvement. The availability of genetic variation is the key prerequisite to successful plant breeding. Plant breeding is focusing on the creation of genetic variation and applying appropriate selection procedures for improvement of quantitative and qualitative characteristics. Sufficient genetic variation offers alternatives from which selections are made for improvement of crop plants. Phenotypic expression is the result of genotype, environment and genotype-environmental interaction and yield is the result of several different factors. Genetic variability, which decides the fate of effective plant breeding program. The existence of tremendous genetic variation and efficient selection are two essential prerequisites in plant breeding. There is a possibility to broaden genetic variability through utilizing wild related species in conventional crosses, whereas novel genetic characters can be obtained through induced mutation. Crop improvement is imperative process to address the increased human population and climate. A success in crop improvement is depending on the quantity of genetic variation exist in the genetic materials and selection for genetically superior genotypes.

\section{References}

1. Emma-Okafor LC, Obiefuna JC, Alagba RA, Okoli NA, Ibeawuchi II, et al. (2016) Evaluation of Selected Tree Leaves as Green Manure Mulch for Sustainable Plantain Production in the Rainforest Agro ecology Of Southeastern Nigeria. International Journal of Agric. And Rural Development 19: 2576-2582. Link: https://bit.ly/3uQOOUr

2. Hodgkin T, Ramanatha Rao V (2002) People, plants and DNA: Perspectives on the scientific and technical aspects of conserving and using plant genetic resources. Managing Plant Genetic Diversity 469-480. Link: https://bit.ly/3aciYOH

3. Swingland IR (2001) Biodiversity, definition of. Encyclopedia of biodiversity 1 : 377-391.

4. Glaszmann JC, Kilian B, Upadhyaya HD, Varshney RK (2010) Accessing genetic diversity for crop improvement. Current opinion in plant biology 13: 167-173. Link: https://bit.ly/2QwPaW1

5. Dyer GA, López-Feldman A, Yúnez-Naude A, Taylor JE (2014) Genetic erosion in maize's center of origin. Proceedings of the National Academy of Sciences 111: 14094-14099. Link: https://bit.ly/2Q76Qb8

6. Mohammadi SA, Prasanna BM (2003) Analysis of genetic diversity in crop plants-salient statistical tools and considerations. Crop Science 43: 12351248. Link: https://bit.ly/3drY0xH

7. Singh SP, Joshi $A B$ (1966) Line $X$ tester analysis in relation to breeding for yield in linseed. Indian J Genet 26: 177-194. Link: https://bit.ly/3do95Qk

8. Jaiswal U, Rai MK, Asthana P, Jaiswal VS (2010) Biotechnological advances in guava (Psidium guajava L.): recent developments and prospects for further research. Trees 24: 1-12. Link: https://bit.ly/3spQyXX
9. Borlaug NE (2000) Ending world hunger. The promise of biotechnology and the threat of antiscience zealotry. Plant Physiol 124: 487-490. Link: https://bit.ly/3eaCRH4

10. Gholami AM, Hahne H, Wu Z, Auer FJ, Meng C, et al. (2013) Global proteome analysis of the NCl-60 cell line panel. Cell Rep 4: 609-620. Link: https://bit.ly/2OTyPdP

11. Bhandari HR, Bhanu AN, Srivastava K, Singh MN, Shreya et al. (2017) Assessment of Genetic Diversity in Crop Plants-An Overview. Adv Plants Agric Res 7: 00255. Link: https://bit.ly/3eaCYT0

12. Smale M, Már I, Jarvis DI (2002) The economics of conserving agricultural biodiversity on-farm. Diversity International. Link: https://bit.ly/3ggButo

13. Cardinale BJ, Duffy JE, Gonzalez A, Hooper DU, Perrings C, et al. (2012) Biodiversity loss and its impact on humanity. Nature 486: 59-67. Link: https://go.nature.com/3xaqkMO

14. Brown WL (1983) Genetic diversity and genetic vulnerability-an appraisal. Economic botany 37: 4-12. Link: https://bit.ly/3e5o0hb

15. Cooper M, Tang T, Gho C, Hart T, Hammer G, et al. (2020) Integrating genetic gain and gap analysis to predict improvements in crop productivity. Crop Sci 60: 582-604. Link: https://bit.ly/3mQcAC5

16. Ray DK, Gerber JS, MacDonald GK, West PC (2015) Climate variation explains a third of global crop yield variability. Nat Comm 6: 1-9. Link: https://go.nature.com/3gftFnO

17. Acquaah G (2009) Principles of plant genetics and breeding. John Wiley \& Sons. Link: https://bit.ly/3gjVBXt

18. Hintum TV, JL T (1995) Hierarchical approaches to the analysis of genetic diversity in crop plants. Core collections of plant genetic resources.

19. Ellstrand NC, Prentice HC, Hancock JF (1999) Gene flow and introgression from domesticated plants into their wild relatives. Annual review of Ecology and Systematics 30: 539-563. Link: https://bit.ly/3agSYBR

20. Ross-Ibarra J, Morrell PL, Gaut BS (2007) Plant domestication, a unique opportunity to identify the genetic basis of adaptation. Proc Natl Acad Sci U S A 104: 8641-8648. Link: https://bit.ly/2QuqKMS

21. Begna T (2020) Importance and Impact of Ecological Approaches to Crop Domestication.

22. Rauf S, da Silva JT, Khan AA, Naveed A (2010) Consequences of plant breeding on genetic diversity. International Journal of Plant Breeding 4: 1-21. Link: https://bit.ly/3mTD8CA

23. McCouch S (2004) Diversifying selection in plant breeding. PLoS Biol 2: e347. Link: https://bit.ly/32j6RLt

24. Pickersgill MARTIN (2005) The taxonomy and ethology of the Afrixalus stuhlmanni complex (Anura: Hyperoliidae), Steenstrupia 29: 1-38. Link: https://bit.ly/3gmybR8

25. Ribaut JM, Banziger M, Betran J, Jiang C, Edmeades GO (2002) Breeding: Drought Tolerance Improvement in Tropical Maize. Quantitative genetics, genomics, and plant breeding 85 .

26. Smith BD (1989) Origins of agriculture in Eastern North America. Science 246 1566 -1571. Link: https://bit.ly/3ackqAD

27. Oladosu Y, Rafii MY, Abdullah N, Hussin G, Ramli A, et al. (2016) Principle and application of plant mutagenesis in crop improvement: a review. Biotechnology \& Biotechnological Equipment 30: 1-16. Link: https://bit.ly/2Q03FIG

28. Yilmaz A, Boydak E (2006) The effects of cobalt-60 applications on yield and yield components of cotton (Gossypium barbadense L.). Pakistan Journal of Biological Sciences 9: 2761-2769. Link: https://bit.ly/3wWBqVs

Citation: Begna T (2021) Role and economic importance of crop genetic diversity in food security. J Agric Sc Food Technol 7(1): 164-169. 
29. Mahagan G, Chauhan BS, Timsina J, Singh PP, Singh K (2011) Crop performance and water-and nitrogen-use efficiencies in dry-seeded rice in response to irrigation and fertilizer amounts in northwest India. Field Crops Research 134: 59-70. Link: https://bit.ly/3ealVPW

30. FAO (2012c) FAO moves to halt plant genetic erosion. FAO Media Centre Food and Agriculture Organization of the United Nations, Rome.

31. Tsegaye B, Berg T (2007) Genetic erosion of Ethiopian tetraploid wheat landraces in Eastern Shewa, Central Ethiopia. Genetic Resources and Crop Evolution 54: 715-726. Link: https://bit.ly/3tpneCi

32. Nabhan GP (2007) Agrobiodiversity change in a Saharan desert oasis, 19192006: historic shifts in Tasiwit (Berber) and Bedouin crop inventories of Siwa, Egypt. Economic Botany 61: 31-43. Link: https://bit.ly/3shGxfq

33. Ford-Lloyd B, Dias SR, Bettencourt E (2006) Genetic erosion and pollution assessment methodologies. Diversity International. Link: https://bit.ly/2QurLVc
34. Maughan PJ, Maroof MS, Buss GR, Huestis GM (1996) Amplified fragment length polymorphism (AFLP) in soybean: species diversity, inheritance, and near-isogenic line analysis. Theor Appl Genet 93: 392-401. Link: https://bit.ly/32xcuGh

35. Nei M (1977) F-statistics and analysis of gene diversity in subdivided populations. Ann Hum Genet 41: 225-233. Link: https://bit.ly/32g8QQS

36. Parzies HK, Spoor W, Ennos RA (2000) Genetic diversity of barley landrace accessions (Hordeum vulgare ssp. vulgare) conserved for different lengths of time in ex situ gene banks. Heredity 84: 476-486. Link: https://go.nature.com/3aaSNYX

37. De Oliveira L, Martins ER (2002) A quantitative assessment of genetic erosion in ipecac (Psychotria ipecacuanha). Genetic Resources and Crop Evolution 49 607-617. Link: https://bit.ly/3spasll

38. Solbrig OT (2000) The theory and practice of the science of biodiversity: a personal assessment. In The Biology of Biodiversity. Springer, Tokyo 107-117. Link: https://bit.ly/3uZlmk7

\section{Discover a bigger Impact and Visibility of your article publication with} Peertechz Publications

\section{Highlights}

* Signatory publisher of ORCID

* Signatory Publisher of DORA (San Francisco Declaration on Research Assessment)

* Articles archived in worlds' renowned service providers such as Portico, CNKI, AGRIS, TDNet, Base (Bielefeld University Library), CrossRef, Scilit, J-Gate etc.

* Journals indexed in ICMJE, SHERPA/ROMEO, Google Scholar etc.

* OAI-PMH (Open Archives Initiative Protocol for Metadata Harvesting)

* Dedicated Editorial Board for every journal

* Accurate and rapid peer-review process

* Increased citations of published articles through promotions

* Reduced timeline for article publication

Submit your articles and experience a new surge in publication services

(https://www.peertechz.com/submission).

Peertechz journals wishes everlasting success in your every endeavours.

Copyright: @ 2021 Begna T. This is an open-access article distributed under the terms of the Creative Commons Attribution License, which permits unrestricted use distribution, and reproduction in any medium, provided the original author and source are credited. 